\title{
6 \\ The Declaration in Comparative Context
}

\section{Introduction}

Self-determination is universally important as a relative and relational political authority. It is also important as a body of political capacities. This chapter examines the ways in which the right to self-determination has been interpreted in various jurisdictions that voted in favour of the Declaration or, in the Russian Federation's case, abstained from the vote. The comparison is instructive both in respect of the scope of the right to self-determination (including the matter of defining what constitutes an indigenous people) and in understanding the effect that prevailing political values and broader conceptions of human rights may have on self-determination's substantive form.

Unlike Australia, Canada, New Zealand and the US, Bolivia and Ecuador incorporated the Declaration into their constitutions, which, for Gussen (2016), makes them 'technically postcolonial' (p. 871). However, like Belize and the Scandinavian states-especially Sweden and Finlandthey display an inconsistent practical regard for the Declaration. In none of these jurisdictions are indigenous peoples satisfied that it is being implemented. Their view is supported by UN special rapporteurs on the rights of indigenous peoples and by independent civil commentators, as discussed in this chapter. In these jurisdictions, indigenous rights to culture are generally accepted along with sometimes significant pluralism in public affairs. However, the extent of such rights is variable, and 
plurality can be limited and conditional. As in the four dissenting states, the most significant point of contention is over the scope of the principle of free, prior and informed consent.

The question of whether self-determination belongs to indigenous peoples only in relation to their own institutions, or whether it also belongs to indigenous peoples within the state as part of a substantive differentiated citizenship, is also contested, though not to the extent of there being no examples of effective indigenous voice as part of an inclusive national polity. In this respect, this chapter's comparative focus draws out lessons that expand or limit the bounds of political possibility.

This chapter's discussion of authoritarian states - the Russian Federation, Fiji and Malaysia-demonstrates the importance of prevailing political values in terms of self-determination and shows that disagreements over the meanings of self-determination and indigeneity occur amid wider uncertainty about the concept of human rights itself. The chapter discusses definitional problems in working out the rights of indigeneity and notes the limits of conflating indigenous and minority rights; such conflation sets geopolitical and cultural relationships aside as the foundational point in indigenous peoples' identity. For the same reason, this chapter contests the notion of indigenous peoples as necessarily subjugated or dominated, as this conception makes indigeneity a temporary political status rather than a permanent cultural one.

The distinction between indigenous and minority ethnic status is an important feature of Ainu politics in Japan. The chapter uses Ainu experience to show the importance of international cooperation among indigenous peoples in asserting the claim to self-determination. It discusses the importance of an indigenous people's self-recognition as indigenous, as well as the importance of mutual recognition by the state to indigenous people's capacity for full and meaningful participation in public affairs.

\section{Participation, Inclusion and Self-Determination}

'Sovereign' indigenous peoples share public authority in the Plurinational State of Bolivia. They coexist as many nations under one state and under a new and inclusive constitution. The Constitution of Bolivia was approved at a public referendum in 2009 and attracted 60 per cent 
support. Coincidentally, Bolivia's constitutional review, which occurred as the Declaration was being developed, was proposed under the leadership of an indigenous state-president (Rice, 2014).

Bolivia’s Constitution recognises 36 indigenous languages. It guarantees proportionate indigenous representation in the parliament and provides for indigenous 'autonomies' as units of local government (Constitución Politica del Estado [Political Constitution of the State] 2009 [Bolivia]). Rice (2014) described these local government arrangements as 'plurinational constitutionalism' (p. 59).

Bolivia's Constitution includes clauses that closely parallel articles in the Declaration. For example, its second article, which corresponds with the Declaration's fourth, asserts that the right to self-determination '[consists in the indigenous] right to autonomy, self-government, their culture, recognition of their institutions, and the consolidation of their territorial entities' (Constitución Politica del Estado, art. 2). Meanwhile, the Declaration affirms that:

Indigenous peoples, in exercising their right to self-determination, have the right to autonomy or self-government in matters relating to their internal and local affairs, as well as ways and means for financing their autonomous functions. (UN, 2007b, art. 4)

Bolivia has the world's most developed public recognition of the Declaration and its principles, yet its full application remains constrained and contested.

Indigenous peoples in Bolivia used the Declaration for the first time in 2011 to resist a highway development that was ultimately approved in 2017. This result notwithstanding, the objection was 'an important test of the state's internationalization of indigenous rights norms'; according to Rice (2014), 'by framing their claims in the Declaration's terms, indigenous groups' went some way towards 'narrowing the gap between legislation and practices' (p. 59).

Conversely, however, Bolivia does not protect non-renewable resources on indigenous lands. The state accepts no obligation to acquire indigenous consent before resource extraction occurs. Therefore, the Bolivian Constitution does not fully change power relations between the state and indigenous peoples' (Rice, 2014, p. 61). Similarly, autonomies are unable to operate according to indigenous decision-making processes. 
These restrictions do not support Rice's further contention that, in taking 'the rights and responsibilities of municipalities', these units of government are 'in essence subverting indigenous governance to the logic of the state' (p. 60).

An alternative explanation is that this kind of independence, which works to undermine notions of an exclusive settler state in binary conflict with indigenous institutions, is a step towards an inclusive plurinational polity in which public institutions are arranged to support independent indigenous participation in decision-making. From this perspective, a more important constraint is that autonomies can only be established in rural areas with majority indigenous populations. Although it is a model available to just half the indigenous population (Rice, 2014), it is one with potential for expansion in respect of geographic coverage, domains of responsibility and culturally cognisant modes of operation. It is also the case that countries such as Ecuador, which has an indigenous population comprising 25 to 30 per cent of the total population, voted for the Declaration because it creates no new rights.

Ecuador saw the Declaration as ensuring the extension of existing human rights norms to indigenous peoples. The country claims to recognise indigenous rights especially in relation to language and land (UN, 2013). The 2008 Constitution of the Republic of Ecuador (Constitución de la República del Ecuador) recognises indigenous rights to culture, land and language, and allows legal pluralism in public affairs. Therefore, in contrast to Rice's (2014) objection in relation to Bolivia, Gussen (2016) argued that, in Ecuador, autonomous indigenous local governments establish the principle of subsidiarity that provides self-determination with an important philosophical foundation.

Subsidiarity complements indigenous participation in national state affairs. It is the idea that decision-making authority is best located as close as possible to the point of policy impact. It informed devolution policies in New Zealand during the 1980s and rationalised the creation of iwi authorities to contract with government to deliver public services with at least some reference to cultural preferences in policy delivery (O'Sullivan, 2007). The principle was imperfectly implemented as contracts were often burdened by excessive reporting requirements and insufficient funding for the work required (Boston, 1996). Nevertheless, the idea that indigenous people should, as far as possible, have the capacity to take responsibility for their own affairs is essential to self-determination. 
Subsidiarity is a logical expression of the right to self-determination in Ecuador. As Gussen (2016) noted:

The fact that there were already international instruments that provided guidance on Indigenous rights meant that the most efficient way forward (as far as obtaining consensus is concerned) was to import these instruments into municipal law, and give a constitutional weight to ensure their implementation. (p. 898)

However, as in other jurisdictions that claimed an advanced commitment to the Declaration, there were broader domestic values that shaped its translation into substantive political practice. In 2013, Ecuador introduced restrictions on freedom of expression and freedom of association. These restrictions contravene Articles 16 and 19 of the Declaration. There are also examples of the harassment of indigenous political actors and of the right to free, prior and informed consent being overridden (Cultural Survival, 2016). Rather than recognising a right to offer or withhold consent, Gussen (2016) explained that Ecuador recognises the right to 'free, prior and informed consultation' (p. 897). Consent and consultation are different concepts. Gussen's example does not unequivocally establish that what is elsewhere regarded as an aspirational goal has 'actually become part of the enforceable domestic law in Ecuador' (p. 898).

Ecuador attempted to justify its use of consultation (as opposed to consent) in response to a UN Human Rights Council Universal Periodic Review (UPR) recommendation from Germany. However, Ecuador's explanation only served to highlight the political inadequacy of consultation in terms of substantive and meaningful participation as part of the state:

The Constitution of the Ecuadorian State establishes consultation as a right of all Ecuadorians, but particularly for communities, peoples and nationalities, a previous, free and informed consultation, but not their consent. Additionally, it is necessary to indicate that Ecuador recognizes the existence of Indigenous Peoples living in voluntary isolation, with the consequent obligation of guaranteeing their lives, of respecting and making others respect their self-determination and will to remain in isolation, and defend the validity of their rights, which turns unviable obtaining their consent. (as cited in Cultural Survival, 2016, p. 5) 
Ecuador's argument was that indigenous rights are qualified and belong only to groups who choose to live in isolation. Such rights are not full and comprehensive rights to self-determination. The country's position demonstrates the importance of the distinction between self-government and self-determination as discussed in Chapter 5.

An alternative approach, and one that is more significant in terms of the breadth of possibilities it creates for interpreting the right to self-determination, is to read the Declaration in conjunction with other instruments including the Universal Declaration of Human Rights (UN, 1948). This foundational document shows the scope of the rights that indigenous peoples share with other citizens within the state:

1. Everyone has the right to take part in the government of his country, directly or through freely chosen representatives.

2. Everyone has the right of equal access to public service in his country.

3. The will of the people shall be the basis of the authority of government; this will shall be expressed in periodic and genuine elections which shall be by universal and equal suffrage and shall be held by secret vote or equivalent free voting procedures. (UN, 1948, art. 21)

These points are not diminished by the greater-though not exclusiveattention that the Declaration on the Rights of Indigenous Peoples places on rights beyond the state. Nor are they diminished by the Declaration's primary focus on state responsibility rather than indigenous capacity, though it is in this respect that the UPR's recommendations to Ecuador did not reflect the breadth of the Declaration's possibilities.

Focusing on states 'doing justice' to indigenous peoples is important, but it is not the same as creating space for indigenous peoples to do justice to themselves. The following illustrative recommendations were supported by Ecuador (parentheses indicate the recommending state in the UPR; UN, 2012b):

Take targeted measures to address the situation of girls and the challenge of ensuring the accessibility to registration for indigenous peoples and people of African descent as well as for migrant families. The right of every child to a name and nationality should be guaranteed (Finland). (s. 135.33) 
Ensure that community activists and indigenous leaders can exercise their right to peaceful assembly and protest and that antiterrorist legislation is not misused to inappropriately censure such activities (Canada). (s. 135.37)

Develop a mechanism to gather statistics on education of indigenous groups. (s. 135.55)

Adopt special measures for the realisation of collective rights of indigenous peoples and the adoption of mechanisms to ensure their right to be consulted (Hungary); Undertake effective measures to further strengthen the existing mechanisms for consultation with the indigenous population on issues which have an impact on the economic and social aspects of the indigenous population (Malaysia); Continue to improve the promotion and protection of the rights of indigenous peoples, in particular the respect of their cultural and linguistic diversity, and further think about programmes and policies for indigenous peoples, particularly focusing on women and children (Morocco); Institutionalize the right to consultation of the indigenous population and involve civil society and indigenous groups in the elaboration of a functioning consultation mechanism in line with Ecuador's commitments under ILO [International Labor Organization]-Convention 169 (Norway). (s. 135.57).

Adopt legislation to guarantee the fulfilment of the collective rights of the indigenous population and Afro-Ecuadoreans, so as to increase affirmative actions in favours of racial and gender equality (Paraguay). (s. 135.58)

The following illustrative recommendation was not supported by Ecuador:

Establish clear consultation procedures in order to implement the right to free, prior and informed consent of indigenous peoples as contained in the Constitution (Germany). (UN, 2012b, s. 136.3)

Belize is another example of a state that supports the Declaration but habitually contravenes its provisions. It does this even though its own Supreme Court found that:

This Declaration, embodying as it does general principles of international law relating to indigenous peoples and their lands and resources of such force that the defendants, representing the Government of Belize, will not disregard it. Belize, it should be remembered voted for it. (as cited in Boyer, 2014, p. 13) 
In its 13-page report to the Human Rights Committee of the International Covenant on Civil and Political Rights, the Maya Leaders Alliance (2018) of Belize argued that:

Despite orders from its own Supreme Court and the Caribbean Court of Justice to do so, the government of Belize has failed to delimit, differentiate, and title the Maya territory, or to meaningfully consult with Maya peoples to protect Maya land rights. The government's failures have resulted in the violation of the Maya peoples' rights to be free from discrimination, rights to self-determination, and rights to property. (p. 1)

The report recommended solutions that were consistent with the Declaration and did not threaten the integrity of the state. They included recognition of a representative body to engage in state policy formation and the full implementation of court orders affirming indigenous claims that are consistent with the Declaration (Maya Leaders Alliance, 2018).

The Maya Leaders Alliance (2018) also argued for the recognition of customary rights, customary systems of government, repair of environmental damage due to logging and other non-Maya commercial activity on Maya lands. In line with the Declaration, it called on the state to:

refrain from acting, or permitting or tolerating third parties to act, in ways that might affect the existence, value, use, or enjoyment of the property located within the geographic area occupied and used by the Maya peoples, until such time as it has developed a mechanism to delineate, demarcate, or otherwise protect Maya lands. (Maya Leaders Alliance, 2018, p. 13)

In Scandinavia, Sami peoples, cultures and traditional livelihoods are constitutionally protected. There are structured opportunities for Sami participation in the public affairs of Denmark, Norway and Sweden, all of which voted for the Declaration. In 2017, together with Finland and Iceland, these states reaffirmed their support for the Declaration: 'The Nordic countries strongly support the Declaration, including its emphasis on the right to self-government and participation. These are central to ensure that the rights of indigenous peoples are respected' (Hattrem, 2017, para. 2).

The Norwegian Government established the Sami Rights Commission in 1980. Its 'positive rights' interpretation of Article 27 of the International Covenant on Civil and Political Rights (UN, 1966a) contributed 
to the establishment of the Sami Parliament (Sámediggi), which has become an important institution and distinctively indigenous part of the state (Broderstad, 2014). Sami self-determination in Norway is best understood from a relational perspective. Broderstad (2014) argued that, while contemporary arrangements are an improvement on the benign interpretations of the International Covenant on Civil and Political Rights that undermined Norwegian assimilationist policies, they do not embody the active protection of distinctive indigenous rights that the covenant imagined, namely:

In those States in which ethnic, religious or linguistic minorities exist, persons belonging to such minorities shall not be denied the right, in community with the other members of their group, to enjoy their own culture, to profess and practise their own religion, or to use their own language. (UN, 1966a, art. 27)

A 'consultation agreement' establishes the terms of the relationship between the Sami and Norwegian parliaments. The agreement proceeds with reference to Convention 169 of the International Labor Organization on indigenous and tribal peoples and its principles of relational justice: 'the rights of indigenous people to consultation, negotiation and real participation in decision-making processes' (Broderstad, 2014, p. 84). According to Broderstad (2014), the 'enhanced recognition of rights expresses both a principle of autonomy and close relations between the Sami and wider political community' (p. 84).

The right to autonomy is an expression of subsidiarity, and the emphasis on relationships with the wider community reflects principles of differentiated citizenship. However, the Norwegian model is limited in the sense that the right to autonomy is restricted to Sami homelands. If the right to self-determination belongs to all peoples, it ought not be restricted in this way.

Broderstad (2014) is careful not to position the agreement as one that guarantees justice. Even in these Nordic jurisdictions, the UN Special Rapporteur on the Rights of Indigenous Peoples argued that it is necessary:

To explore ways to ensure that there is policy coherence between the positions they take in international human rights forums and those they take at home ... the standards of the final [policy] outcome should not be lower than those to which all three states have committed in endorsing the Declaration. (UN, 2016b, p. 6) 
The special rapporteur recommended that the Norwegian Sami Parliament be granted a role in the 'oversight and evaluation of Sami education programs and their quality' (UN, 2016b, p. 20). The rapporteur also recommended better support for Sami languages of which there are nine-each of them 'threatened' or 'extremely threatened' (p. 6).

The special rapporteur made similar recommendations to the Swedish state. Critical of that country's Sami language policy, she was blunt in her 'encouragement' of Sweden 'to introduce reforms to ensure that the Sami Parliament has greater independence from State institutions and authorities' (UN, 2016b, p. 20). She urged Sweden to review the Sami Parliament's statutory status and function in relation to government institutions and to ensure that adequate funding was allocated for the parliament to carry out its work as a popularly elected body (UN, 2016b).

The special rapporteur had earlier recommended that Norway strengthen mechanisms for assessing land and resource claims, and had proposed more effective consultative measures and arrangements for the settlement of these claims. She also proposed stronger measures to protect indigenous interests in relation to commercial mining licences, arguing that Sami interests ought to be managed consistently with contemporary human rights values (UN, 2016b). Norway is yet to adopt the recommendations (UN, 2016b). Nevertheless, it is an important measure of relational justice that, under the Norwegian consultation agreement, most of the 40-50 consultations that occur each year lead to concurrence on legislation. The agreement makes consensus possible in ways not achievable in Australia, for example, because, as objections to the idea of a guaranteed indigenous voice to parliament show, there is no political agreement that an entrenched procedure for meaningful participation should in fact exist.

The Norwegian and Swedish Sami parliaments are popularly elected; however, they differ in their broader structures and capacities to influence national public policy. The Norwegian Sámediggi was established to 'enable the Sami people in Norway to safeguard and develop their language, culture and way of life'; by contrast, the Swedish Sámediggi was established as a 'special government agency' (Josefsen, Mörkenstam \& Saglie, 2015, p. 37). In Norway, the Sámediggi may consider 'any matter that in the view of the Sami parliament particularly affects the Sami people'; in Sweden, the Sámediggis authority is to 'monitor issues related to Sami culture' in that country (Josefsen et al., 2015, pp. 37-38). The parliaments provide voices to government-not voices in government. 
In relation to Australia, this distinction may be instructive as the country works out the functions of its proposed Indigenous voice to parliament (see Chapter 7).

The UN special rapporteur found that, relative to Norway, Sami opportunities for self-determination in Finland were severely restricted. The rapporteur's recommendations to the Finnish Government were comprehensive and concerned elementary breaches of the right to selfdetermination. There were unresolved differences between the state and Sami people on the functions that the Sami Parliament ought to enjoy, and Sami interests in relation to mining were inadequately protected. According to the special rapporteur, Sami people in Finland were not properly included in decision-making over the use of forestry lands, which has significant implications for the right to culture. It also has significant implications for the provision of education. The special rapporteur argued that Finnish public education did not adequately contribute to the linguistic and cultural aspects of the right to self-determination (UN, 2016b).

The special rapporteur stressed the importance of people being able to make decisions about the distribution of adequate resources. The importance of this capacity for self-determination appeared in the observation that the 'solution' to cultural and linguistic revitalisation lies in further strengthening indigenous peoples' ability to develop and implement their own programs for economic development and job creation, education, preservation and development of cultural expression and knowledge, and public order, including the protection of women and children (UN, 2016b).

In January 2017, Sami peoples and Finland, Norway and Sweden concluded negotiations on a common framework for the implementation of the right to self-determination. However, the resulting Sami Convention was contested and, by December that year, had been returned to the Sami parliaments for further negotiations. The Norwegian National Human Rights Institution was not convinced that the convention, which privileges the right to consultation over the right to full democratic participation complied with the Declaration.

According to the Sami parliaments, the states' consultative efforts reflect the limits of consultation as a pathway to self-determination. Nevertheless, as a reflection of the inconsistencies and uncertainties 
that universally distinguish indigenous public policy, all three states are working to strengthen consultation's legal basis (International Work Group for Indigenous Affairs, 2018). Also, in marked contrast with Australia, the Sami Convention recognises free, prior and informed consent as an essential constituent of the right to self-determination. Like Canada, the Norwegian Parliament has established a Truth Commission to consider the effect of state assimilation policies. Sweden and Finland are contemplating similar measures. Broderstad (2014) argued that 'by making use of the political rights of citizenship', Sami people in Norway have 'had significant breakthroughs in terms of their political influence and ability to self-govern' (p. 74). Subsequent chapters of this book develop theoretical arguments on the relationship between self-determination and public sovereignty, exploring possibilities for noncolonial expressions of citizenship, sovereignty and democracy, and concluding that the Declaration provides important moral and political guidance on the strengthening of these relationships.

\section{The Right to Self-Determination and the Politics of Definition}

The Russian Federation is the only nonliberal state that exists over Sami territory. Significantly, it did not participate in discussions on the Sami Convention and abstained from the vote to adopt the Declaration. It does not routinely acknowledge indigenous fishing and other natural resource rights or the principle of free, prior and informed consent (International Work Group for Indigenous Affairs, 2018). The state's general restrictions on political expression further compromise the right to self-determination. The UN Committee on the Elimination of Racial Discrimination observed that:

Russia had again failed to provide disaggregated data on the socio-economic status of indigenous peoples and other vulnerable groups, something that had been explicitly requested by the committee in the previous concluding observation. It also noted with concern the broad application of the term 'extremism' to silence indigenous and other organisations ... Further concerns and recommendations were noted regarding indigenous land rights, specifically Russia's failure to create federally protected Territories of Traditional Nature Resource Use, irreparable harm 
caused to indigenous land by extractive industries and denial of hunting and fishing rights. (International Work Group for Indigenous Affairs, 2018, p. 47)

In 2013, the Russian Federation informed the UN special rapporteur of the politically significant fact that indigenous peoples in that country had not been colonised. The special rapporteur agreed that this was true but argued that they shared with indigenous peoples elsewhere 'marginalisation and other struggles arising from their minority status' (UN, 2013, Interactive dialogue, para. 4). This argument understated the significance of geopolitical associations, and also of indigeneity itself, as geopolitical associations are inescapably determinants of what it means to be indigenous.

Newcomb (2011) similarly understated the meaning of indigenous by adopting 'dominated peoples' (p. 578) as his definition of indigeneity. The indigenous experience in Fiji, for example, shows this definition's inherent and far-reaching limits. Indigenous Fijians comprise more than 50 per cent of their country's population and are not dominated by another ethnic group. However, their contemporary politics is shaped by colonial experience, state rejection of many of the claims that they make by virtue of prior occupancy, and conflict over land and natural resource use. These claims of indigeneity are usefully evaluated with reference to the Declaration (O'Sullivan, 2017), which will not 'overturn' domination as Newcomb (2011) observes, but may, over time, influence the ways people think about the configuration of the state and the place that indigenous peoples occupy within it. Certainly, it is a gross overstatement to argue that 'not one of the [Declaration's] 46 Articles ... addresses the issue of domination' (Newcomb, 2011, p. 579).

Fiji's vote in favour of the Declaration was conditional. It noted that the Declaration may not have been adopted if the UN General Assembly had insisted on consensus on the full scope of the right to selfdetermination (UN, 2013). It did not accept that an indigenous right to self-determination was applicable in its own jurisdiction. For Fiji, demography (i.e. the indigenous population's majority status) trumped culture and geopolitical attachment in its definition of indigenous. Nor could Fiji accept a definition of self-determination if it threatened the territorial integrity of any state and rejected the idea that prior occupancy could justify ethnic privilege for indigenous people (UN, 2013). 
Ethnic privilege is an argument often raised to discredit indigenous claims. It has some justification in Fiji where there is a history of interpreting indigenous 'paramount' political authority as creating political rights depending on others' exclusion by, for example, limiting appointment to the offices of president and prime minister to indigenous Fijians (O'Sullivan, 2017). Similarly, while the three coups and putsch that have overthrown governments since 1987 were vastly more complex than a politics of ethnic struggle, all but the most recent were expressed by the perpetrators as claims to the rights of indigeneity (O'Sullivan, 2017).

Conversely, ethnic privilege is raised to discredit land rights claims in Australia. In 2018, member of the Australian Parliament and leader of the One Nation Party Senator Pauline Hanson said that she 'gets really upset when people say this is Aboriginal land' (Khalil, 2018, para. 2). Ethnic privilege is also used to justify the narrow and exclusive liberalism of people like the former Australian prime minister John Howard (see Chapter 3).

The Declaration's ultimate concern is the codification of rights, not the codification of privilege. The distinction between rights and privileges would nevertheless be especially helpful to Fijian indigeneity's conceptualisation of a just and robust body of political capacities and responsibilities. It would also help to conceptualise and express just claims against the state (O'Sullivan, 2017). The Declaration shows that indigenous claims to distinctiveness - to live and participate in public life as indigenous - need not be claims to privilege.

Doubts about the Declaration's applicability to Fiji deprive that country of a moral and legal framework likely to contribute to a more just and stable political order (O'Sullivan, 2017). The Declaration would assist the Fijian politics of indigeneity to develop theoretical consistency and cohesion as well as a pragmatic account of the self-determination that Fijian people seek, which neither majority population status nor the ethnicity of the prime minister or president can achieve.

To take the argument further, Bowen (2000), in questioning whether 'a reversal in political fortunes could create newly "indigenous" peoples out of formerly dominant ones' (p. 13), exposed the problem with defining indigenous with reference to domination. The politics of indigeneity's defining purpose is to achieve substantive and enduring self-determination; in other words, nondomination. A people does not cease to be indigenous 
when it ceases to be dominated. From this perspective, Martinez Cobo's (1981) widely accepted working definition of an indigenous people is limited and limiting:

Indigenous communities, peoples and nations are those [that], having a historical continuity with pre-invasion and pre-colonial societies that developed on their territories, consider themselves distinct from other sectors of the societies now prevailing in those territories, or parts of them. They form at present non-dominant sectors of society and are determined to preserve, develop and transmit to future generations their ancestral territories, and their ethnic identity, as the basis of their continued existence as peoples, in accordance with their own cultural patterns, social institutions and legal systems. (p. 379)

The question of domination or nondomination is shrouded in greater complexity than Martinez Cobo's definition can address. Peoples' perceptions of rights are culturally conditioned. Fiji's majority indigenous population, for example, views indigeneity as a source of political rights for much the same reasons as the minority indigenous populations of Australia and New Zealand (O'Sullivan, 2017).

Domination and subjugation can only describe a contemporary circumstance, yet the Declaration's point is to establish an enduring politics of nondomination. The Fijian case shows the contested nature of the meaning of domination and the different perspectives that indigenous people hold of the relationship between domination and substantive self-determination. Nor does an indigenous group dominating others, as has occurred in Fiji, guarantee its self-determination (O'Sullivan, 2017). Power relationships are not so simple; their complexities need to be understood and the limits ofas well as the possibilities for-self-determination worked out. As the Fijian case shows, the desire to lose the status of nondominance does not suggest losing the status of indigeneity because indigeneity describes a political status only after it describes a cultural one.

The indigenous chief executive of Fiji's Citizens' Constitutional Forum, Akuila Yabaki, argued that the Declaration would contribute to indigenous Fijians' self-determination by recognising:

our right to be different, and to act as an individual or as part of a community as we choose. It encourages participation in matters [that] affect us all such as education, social welfare, health, environment and governance without discrimination. 
From it we should learn that multiculturalism is what makes us all part of the common heritage of mankind. We are all entitled to exercise and practice our beliefs, cultures and religions, and should not interfere in the rights of other people to do the same. (Yabaki, 2011, para. 10)

This account of political authority allows corporate indigenous membership of a single national polity alongside the rights and responsibilities of indigenous citizenship. A further distinction with Canada and New Zealand is that, in those jurisdictions, the rights of citizenship are liberal political rights. While institutional racism impedes their realisation, political rights are not constitutionally limited as they are in Fiji. Indeed, the Declaration indicates that the relationship between individual liberty and group rights is circuitous and interdependent, with each being equally important missing constituents of the Fijian right to self-determination (O’Sullivan, 2018a).

There should be no question of the Declaration's applicability to Fiji. As UN special rapporteur James Anaya (2008) explained:

The basic normative justification of the Declaration is stated in the sixth preambular paragraph, which acknowledges that 'indigenous peoples have suffered from historic injustices as a result of, inter alia, their colonization and dispossession of their lands, territories and resources, thus preventing them all from exercising, in particular, the right to development in accordance with their own needs and interests'. (p. 16)

Indigenous Fijians fit Watson and Venne's (2012) description of peoples who 'have not been able to decolonize' (p. 93). Although they have recovered their majority population status and have been able to dominate national political institutions, they have not been able to translate power into meaningful opportunities. The reasons are complex and multifaceted (O'Sullivan, 2017, 2018a). They show that indigenous politics is not distinguished by what Carroll (2012) described as the 'imperial binaries' of 'assimilation or secession' (p. 156).

The extension of the Declaration's terms and provisions to Fiji is legitimate and efficacious. The withdrawal of colonial power has not removed the constraints placed on postcolonial indigenous self-determination (O'Sullivan, 2017, 2018a). The native Fijian experience as a people excluded from normative definitions of 'indigenous', and thus from the Declaration's provisions, provides a point of contrast. 
Durie (1998) explained why, from a Maori perspective, one cannot accept indigeneity as a temporary status belonging to a people while they are 'oppressed' but not once they have successfully contested that oppression:

A firm Māori identity ... [requires] access to whānau, hapū, and iwi and confirmation that future generations of Māori will be able to enjoy their lands and forests, rivers and lakes, harbours and the sea and the air. These goals underlie the significance of Māori selfdetermination. (p. 239)

Ainu experiences in Japan also show indigenous peoples making geopolitics-rather than just politics-fundamental to their identity and ensuing political claims. Ainu attach great significance to public recognition of their status as indigenous people as distinct from an ethnic minority.

\section{Rights and Recognition}

Although Japan voted for the Declaration, its recognition of the distinction between Ainu as an indigenous population and Ainu as an ethnic minority has been mixed and conditional. Its vote for the Declaration occurred in a climate of philosophical inconsistency, and, by 2007, it had not ratified the International Labor Organization's convention (Convention 169) on indigenous and tribal peoples (International Work Group for Indigenous Affairs, 2018).

From 1899 until 1997, Ainu policy was managed under the Hokkaido Former Aborigines Protection Act. In 1997, a proposed 'New Ainu Law' became a point of contention between Ainu people and the state. The UN Special Rapporteur on Contemporary Forms of Racism, Racial Discrimination, Xenophobia and Related Intolerance was concerned that the proposed law focused only on narrowly defined conceptions of culture, and argued that:

The Ainu want to see included in this law the recognition of their status as indigenous peoples, the promotion of their indigenous rights in conformity with international law, and the fight against the discrimination they face. However, the Government has not acceded to this request ... They are among the few indigenous peoples in the world who have no land recognized as their indigenous land. (UN, 2006a, para. 49) 
Indigenous claims against the state are supported by an international indigenous politics that predates cooperation on the Declaration. The Ainu claim to self-determination benefited from the globalisation of indigenous political thought and practice that occurred during the 1970s. International cooperation propelled Ainu political activity 'into large-scale social movements' (Tsutsui, 2018, p. 42). Most importantly, it created a political focus 'beyond dependence on the government toward a more full-throated assertion of their rights as indigenous people' (p. 42). For a people whose indigeneity was denied by the state, the evolution of new internationally sanctioned norms of justice was especially significant. Recalling a visit to a Canadian First Nation in 1978, an Ainu observed:

To my complete amazement, when I stepped out of the gate at the Vancouver airport, I was greeted by a group of indigenous people performing their traditional dance in their traditional costume. It was shocking to me that an indigenous people could exhibit its traditional culture with such pride in a highly modernised setting of an international airport ... The leader of the indigenous people told us that they are trying to organise a conference on indigenous peoples and the UN and encouraged us to be a part of it. To us, the UN was like a different world and it just didn't seem realistic that we could be part of such a conference. (as cited in Tsutsui, 2018, p. 47)

This story of the normalisation of indigenous culture in the public space, and of indigenous political expression, documents a step towards indigeneity's mainstreaming — a contested and tortuous, but nevertheless important, process.

Mainstreaming indigeneity is important because it contributes to recasting 'otherness' from political marginalisation to the positive assertion of distinctive presence (O'Sullivan, 2017). It is a statement that we are among the 'all' who 'are here to stay'. Its intent is to bring the human rights of indigenous peoples into the mainstream of political thought. The Declaration contributes by providing indigenous peoples with nonstate benchmarks and value systems against which to define their claims in language that, in liberal societies at least, makes sense to the state. At the same time, domestic indigenous politics is exposed to new ideas about what is just and how justice might be pursued.

Human rights are not conditional on conforming to externally imposed values and modes of behaviour; yet it is indigenous peoples' reluctance to conform to the values and expectations of majority populations that 
leads to social isolation and political exclusion. The tension between group rights and individual rights is a significant demonstration of this reluctance. The indigenous desire to privilege collective rights to land as a source of material sustenance and spiritual meaning contrasts with views of land as an exploitable commodity.

In 1980, Japan told the UN Human Rights Committee that ethnic, religious and linguistic minorities do not exist in that country. However, by 1987, international and domestic pressure led Japan to change its position. The government told the UN Working Group on Indigenous Populations that it "does not claim that Japan is "a mono-ethnic state" nor does it deny the existence of Ainu people' (Tsutsui, 2018, p. 58). Its vote for the Declaration was followed by parliamentary recognition of Ainu indigeneity in 2008.

However, recognition does not always lead to meaningful political influence. The broader political context in which indigenous claims are made are also important. Just as the Russian Federation's authoritarian political culture limits all people's fundamental freedoms, Malaysia's recognition of 13.8 per cent of its population as indigenous does not set aside state hegemony. Malaysia voted for the Declaration, and its constitution protects native customary rights, yet the provisions of both are routinely violated (Cultural Survival, 2018). In its 2018 submission to the UN Human Rights Council UPR, the international nongovernment organisation Cultural Survival (2018) argued that Malaysia continues to 'initiate' contraventions of land rights; disregard the right to free, prior and informed consent; and not take adequate measures to confront violence against women.

In Sarawak, indigenous peoples faced (and continue to face) displacement due to dam construction. Though a number of dams forming part of a proposed 12-dam project were discontinued, partly due to indigenous resistance, others were planned that would add to human displacement (Cultural Survival, 2018). Conversely, in 2015, the federal Cabinet established a committee for the land rights of indigenous peoples, which prioritised improvements to land administration, infrastructural development, education and training for young people, increasing sustainable economic activity, assistance for people in the bottom two income quintiles and improvements in public service delivery (Human Rights Commission of Malaysia, 2017). 
Such tensions between the general authoritarianism of states like Malaysia and the Declaration's human rights principles are important. The Special Rapporteur on the Rights of Indigenous Peoples told a committee of the UN General Assembly in 2013 that 'Without greater awareness of the human rights values and concerns encompassed in [the Declaration], its implementation would be "difficult, if not impossible"' (UN, 2013, para. 1).

Different perspectives on what ought to comprise the minimum rights of indigenous peoples reflect different perspectives on the source of those rights. Are rights the state's to confer as an expression of its sovereignty or do they belong inherently by virtue of humanity? Are they contextualised by virtue of one's indigeneity? If human rights belong inherently and are not the gift of state benevolence, one strengthens the capacity for selfdetermination to develop as a worthwhile relative and relational politics. However, authoritarian states carefully safeguard sovereignty, not just against external interference but also against the claims of people living under their rule. They can rationalise voting for the Declaration to satisfy the interests of international diplomacy while giving it minimal domestic recognition on the basis that it is simply aspirational.

The Indigenous Peoples Network of Malaysia (2013) represents 62 indigenous communities and organisations. Its simple but profoundly important opening argument to the UPR in 2013 was that:

Collectively our peoples count as among the most poor in Malaysia, due to marginalisation from the mainstream society on account of the non-recognition of our rights as contained in both national and international customary law. ('Context', para. 1)

The submission identified violations of the Declaration in respect of land; free, prior and informed consent; self-governance; intimidation and harassment by public authorities; and violations of the right to citizenship. Interestingly in terms of this book's arguments for indigenous political authority inside the state, the submission also requested UN advocacy and capacity-building assistance that would 'contribute to expanding opportunities for indigenous peoples to participate meaningfully in the development of Malaysia, while maintaining our laws, customs, and identity' (Indigenous Peoples Network of Malaysia, 2013, Needs of Malaysia and role of UN, para. 3). 
China is another authoritarian Asian state that voted for the Declaration. In contrast to its prevailing approach to human rights, it 'stressed' in 2013 to a committee of the UN General Assembly that the international community has a duty to ensure that indigenous peoples share the 'fruits of socioeconomic development, to protect their basic human rights and fundamental freedoms, and to preserve their natural environment and the traditional cultures essential for their survival' (UN, 2013, Statements, para. 12). In 2016, Taiwan apologised to indigenous peoples for previous policy positions and, in 2017, passed legislation giving indigenous languages official status. Taiwan's formal recognition of 14 other indigenous groups, who are guaranteed representation in parliament (International Work Group for Indigenous Affairs, 2018), casts as politically extreme the Australian suggestion that a guaranteed indigenous voice to parliament would threaten national political cohesion (Belot \& Laurence, 2017).

The office of the Taiwanese president had also established a broadly representative committee:

to check into violations against indigenous peoples throughout history; to formulate measures to provide compensation for deprivation of indigenous rights; to implement [the Declaration] and the relevant international rights convention; [and] to collect and review information regarding indigenous historical justice and transitional justice. (International Work Group for Indigenous Affairs, 2018, p. 276)

According to Conway-Long (2016), indigeneity poses the same fundamental questions to all states, whether liberal or illiberal:

Can international law [and politics] be utilized to free indigenous people both politically and culturally, now that the UN has declared its interest? ... Can indigenous issues bring pressure upon the system of international law to help transform it from the Eurocentric vision of states' rights rooted in the Westphalian Peace it now has? (p. 116)

This transformation is precisely the politics of indigeneity's point. The comparison between liberal and illiberal states is also instructive in moving beyond a theoretical to a practical understanding of self-determination that is ultimately concerned with a people's capacity 'to live well and humanly in their own ways' (Conway-Long, 2016, p. 116). 
Liberal states constrain indigenous aspirations to protect both their own integrity and what majority populations hold in common. However, as Corntassel (2012) explained, this does not foreclose opportunities for selfrecognition, which is an essential condition of self-determination. The Ainu experience illustrates this point: it shows self-recognition as a form of political expression that does not exist in nonliberal states that view protecting their own authority as an overriding state political objective. Self-recognition precedes liberal mutual recognition, which, though usually unequal for indigenous peoples in postsettler liberal states, still assures indigenous peoples of at least some capacity for political influence. For example, as Chapter 9 shows, the Canadian state requires at least some cooperation with indigenous citizens to pursue its economic aspirations.

In jurisdictions like Ecuador, Taiwan, Malaysia and the Russian Federation, state recognition is essential. Structural limits on an indigenous people's political capacity to claim their indigeneity by and for themselves limits the Declaration's transformative potential. In spite of the examples of Taiwanese respect for the Declaration noted in this chapter, there remain indigenous peoples in Taiwan-the Pingpu population of 400,000who have not received state recognition of their indigeneity even though 'recognition is fundamental ... to the enjoyment of a number of specific rights under Taiwanese and international law' and is viewed as safeguarding 'the cultural identity of aboriginal tribes and individuals' (van Bekhoven, 2016, p. 202).

Although liberal societies share the practice by which the 'law determines the indigenous status of communities and individuals that claim this status' (van Bekhoven, 2016, p. 202), indigenous peoples in those jurisdictions have recourse to a political framework more conducive to resistance, and they use it to assert their self-determination. In contrast, the limited capacity for self-recognition in a jurisdiction like Taiwan allows the state to be more successful in assuming an 'exclusive concept of being "indigenous" (p. 202). The ensuing 'artificial indigenous identity ... results in a persisting colonial dominance of the State over the aborigines' (p. 202). In contrast, human rights are the capacities of citizenship. They are intended to raise political agency. As human rights are vested in people, they make people prior to the state with the capacity to contest state authority. 
There is no normative internationally accepted conception of the balance between human rights and state rights; therefore, the minimum standards reflected in the Declaration represent an extraordinary political achievement and comprehensive blueprint for thinking about political relationships and reasonable policy outcomes. However, the Declaration is still more heavily focused on the obligations of states rather than the capacities of people. A conception of rights that is truly grounded in the inherent dignity of the human person would reverse this order.

\section{Conclusion}

The Declaration is inconsistently interpreted by states that voted for its adoption. Those states also contest the scope of the right to selfdetermination. The incorporation of principles that correspond with the Declaration into national constitutions does not necessarily mean that the rights of indigenous peoples are better respected than in other jurisdictions. Nor does a generally authoritarian political culture mean that indigenous rights are completely set aside.

In general, states are inclined to accept rights to culture; however, most view the principle of free, prior and informed consent as too much of a constraint on state sovereignty. The impasse between states and indigenous peoples on this point is resolvable only within the broader conceptions of sovereignty, citizenship and democracy that this book advances. These conceptual discussions are also important to questions of whether the right to self-determination is confined to indigenous institutions that exist in isolation from the state or whether it is also a right reasonably exercised within the state. The nature of indigenous participation in public affairs varies widely across jurisdictions.

The definition of indigenous, which is important in establishing the source and purpose of indigenous claims, is also contested. This book's argument that minority status and political domination are not essential criteria for recognition as indigenous informs its conception of the rights of indigeneity. It also informs its evaluation of the Declaration's usefulness to contemporary indigenous politics. The book's further argument is that accepting a majority indigenous people—like that in Fiji-as indigenous is also essential to a consistent account of indigeneity as first and foremost a cultural status. 
In short, self-determination's possibilities are shaped by domestic practices of sovereignty. As the next chapter argues, the right to self-determination means that all people are entitled to share in the public authority of the communities in which they live. Sovereignty is not an absolute, inflexible and unchanging site of political authority. It is widely dispersed among individual and institutional actors-the following chapter shows how and why. It also shows how rethinking the nature of sovereignty in liberal societies broadens self-determination's scope and value to indigenous peoples. 
This text is taken from 'We Are All Here to Stay': Citizenship, Sovereignty and the UN Declaration on the Rights of Indigenous Peoples, by Dominic O'Sullivan, published 2020 by ANU Press, The Australian National University, Canberra, Australia.

doi.org/10.22459/WAAHTS.2020.06 